\title{
Analisis Kesalahan Siswa dalam Menyelesaikan Soal Persamaan dan Pertidaksamaan Nilai Mutlak Berdasarkan Langkah Penyelesaian Polya
}

\author{
Mila Nuryah ${ }^{1}$, Ferry Ferdianto ${ }^{2 *}$, Supriyadi ${ }^{3}$ \\ 1,2 Universitas Swadaya Gunung Jati, ${ }^{3}$ SMAN 1 Gegesik \\ *ferry.ugj@gmail.com
}

Diterima: Oktober 2019. Disetujui: Desember 2019. Dipublikasikan: Januari 2020.

\begin{abstract}
ABSTRAK
Penelitian ini adalah penelitian deskriptif kualitatif yang bertujuan untuk menganalisis jenisjenis kesalahan dan persentase kesalahan yang dilakukan siswa kelas X MIPA 2 SMA Negeri 1 Gegesik dalam menyelesaikan soal persamaan dan pertidaksamaan nilai mutlak berdasarkan langkah penyelesaian Polya. Metode yang digunakan adalah metode penelitian yang digunakan adalah metode deskriptif kualitatif dengan menggunakan instrumen pengumpulan data berupa soal tes esai dan lembar wawancara. Instrumen yang digunakan terlebih dahulu diuji validitasnya. Subjek penelitian ini adalah 36 siswa kelas X MIPA 2 SMA Negeri 1 Gegesik. Penyelesaian soal persamaan dan pertidaksamaan nilai mutlak berdasarkan langkah penyelesaian Polya terdiri dari empat tahap, yaitu memahami soal, menyusun rencana, melaksanakan rencana, dan memeriksa kembali solusi yang diperoleh. Fokus penelitian ini adalah meneliti jenis kesalahan siswa, jenis kesalahan yang dimaksud dalam penelitian ini adalah jenis kesalahan berdasarkan langkah penyelesaian Polya, yaitu kesalahan memahami soal, kesalahan menyusun rencana, kesalahan melaksanakan rencana, dan kesalahan memeriksa kembali solusi yang diperoleh. Hasil penelitian yang dilakukan menunjukkan bahwa terdapat empat jenis kesalahan yang dilakukan siswa kelas X MIPA 2 SMA Negeri 1 Gegesik dalam menyelesaikan soal persamaan dan pertidaksamaan nilai mutlak berdasarkan langkah penyelesaian Polya, yaitu kesalahan memahami soal sebesar $38 \%$; kesalahan menyusun rencana sebesar 14\%; kesalahan melaksanakan rencana sebesar $24 \%$; dan kesalahan memeriksa kembali solusi yang diperoleh sebesar $24 \%$.
\end{abstract}

Kata kunci: analisis kesalahan, persamaan dan pertidaksamaan nilai mutlak, Polya.

\section{ABSTRACT}

This research is a qualitative descriptive study that aims to analyze the types of errors and the percentage of errors made by students of grade X MIPA 2 in SMA Negeri 1 Gegesik in solving problems of equality and inequality of absolute values based on Polya's completion steps. The method used is the esai test method and the interview method. The subjects of this study were 36 students of class X MIPA 2 of SMA Negeri 1 Gegesik. The solution of equality questions and absolute value disputes based on Polya's completion steps consists of four stages, namely understanding the questions, preparing plans, implementing plans, and reexamining the solutions obtained. The type of error referred to in this study is the type of error based on Polya's completion steps, which is an error in understanding the problem, an error in preparing the plan, an error in implementing the plan, and an error in re-checking the solution obtained. The results of the study showed that there were four types of errors made by students of Class X MIPA 2 of SMA Negeri 1 Gegesik in solving problems of equations and inequality of absolute values based on Polya's completion steps, namely errors understanding problems by 38\%; mistakes in making a plan by $14 \%$; mistakes in implementing the plan by 24\%; and errors re-checking the solution obtained by $24 \%$.

Keywords: error of analysis, equality and absolute value inequality, Polya.

How to Cite: Nuryah, M., Ferdianto, F., \& Supriyadi. (2020). Analisis Kesalahan Siswa dalam Menyelesaikan Soal Persamaan dan Pertidaksamaan Nilai Mutlak Berdasarkan Langkah Penyelesaian Polya. Journal of Medives: Journal of Mathematics Education IKIP Veteran Semarang, 4(1), 63-70. 


\section{PENDAHULUAN}

Ilmu pengetahuan dan teknologi mengalami kemajuan yang sangat pesat pada era global seperti saat ini. Tidak dapat dipungkiri bahwa hal tersebut juga dipengaruhi oleh peran matematika sebagai salah satu cabang ilmu pengetahuan yang banyak mendasari perkembangan ilmu pengetahuan yang lain. Oleh karena itu, matematika perlu disampaikan sejak dini, dengan tujuan agar siswa mampu berfikir kritis, logis, sistematis, cermat, efektif, dan efisien dalam memecahkan masalah (Permendiknas No. 22 Tahun 2006). Matematika sebagai sarana untuk menanamkan kebiasaan menalar. Matematika merupakan pelajaran yang sangat penting dalam menunjang kehidupan manusia. Matematika sebagai pondasi untuk membangun penalaran perlu diberikan pada semua siswa di semua tingkatan. Hal tersebut mencerminkan bahwa matematika merupakan salah satu ilmu yang sangat penting untuk diajarkan karena banyak sekali peranan matematika dalam kehidupan manusia, Cooney \& Cotton (Khiat, 2010: 1461) menyampaikan bahwa peserta didik memandang matematika sebagai hal yang menarik dan sebagian lagi memandang bahwa matematika adalah hal yang membosankan. Sedangkan Hoyles (Khiat, 2010: 1461) mengatakan bahwa beberapa siswa memandang matematika sebagai subjek yang menyebabkan ketakutan, kecemasan dan kemarahan selama pelajaran. Dalam mata pelajaran matematika, biasanya suatu masalah dijumpai dalam bentuk pertanyaan atau soal matematika yang harus diselesaikan oleh siswa. Suatu soal matematika dapat menjadi masalah matematika jika siswa tidak mampu menemukan suatu solusi untuk menyelesaikan permasalahan tersebut tetapi mempunyai keinginan untuk menyelesaikannya. Hal ini sependapat dengan Widodo (2015: 51) yang mengatakan bahwa suatu soal matematika dapat menjadi masalah matematika jika peserta didik tidak mempunyai gambaran untuk menyelesaikannya, tetapi peserta didik tersebut berkeinginan untuk menyelesaikan masalah matematika tersebut. Lain halnya jika peserta didik tersebut mempunyai gambaran untuk menyelesaikan masalah maka soal matematika tersebut tidak menjadi masalah bagi peserta didik. Walaupun setiap individu mempunyai masalah matematika yang berbeda-beda tetapi setiap peserta didik tidak dapat menghindar dari kesulitankesulitan dalam belajar matematika.

Dalam proses pembelajaran, masih sering terjadi pada peserta didik yang melakukan kesalahan dalam menyelesaikan soal matematika. Hal tersebut dapat diketahui dari beberapa hasil penelitian yang dilakukan di beberapa jenjang yang berbeda, di antaranya adalah hasil penelitian dari Fitria (2013), bahwa jenis kesalahan yang dilakukan siswa adalah kesalahan terkait konsep, operasi, fakta dan prinsip. Berdasarkan hasil penelitian Lipianto \& Budiarto (2013) siswa melakukan kesalahan konsep, prinsip dan operasi; sedangkan berdasarkan hasil penelitian Elbrink (2008) siswa biasanya melakukan kesalahan perhitungan, prosedur dan simbolik. Selain hasil dari penelitian-penelitian tersebut masih banyak lagi penelitian lainnya yang mengkaji kesalahan yang dilakukan 
peserta didik dalam mengerjakan soal matematika. Berdasarkan (Brown \& Skow, 2016) mengatakan bahwa analisis kesalahan telah terbukti menjadi metode yang efektif untuk mengidentifikasi pola dari kesalahan matematis siswa. Untuk mengidentifikasi kesalahan matematis siswa, diperlukan strategi khusus untuk dapat memecahkan masalah matematika khususnya mengenai soal persamaan dan pertidaksamaan nilai mutlak, salah satunya yaitu dengan menggunakan langkah penyelesaian Polya. Menurut Polya (1973) langkah-langkah dalam pemecahan masalah matematika antara lain: (1) memahami masalah, (2) merencanakan pemecahan masalah, (3) melaksanakan rencana pemecahan masalah, dan (4) memeriksa kembali solusi yang diperoleh (Lya, S 2019).

Berdasarkan pendapat tersebut penelitian terkait analisis kesalahan sangatlah penting dan dapat dikembangkan agar para pengajar mengetahui kesalahan apa saja yang dilakukan oleh siswanya sehingga pengajar dapat mengidentifikasi dan meninjau kesalahan yang sering dilakukan oleh siswa yang pada akhirnya dalam proses pembelajaran pengajar dapat memilih strategi yang tepat agar siswa tidak melakukan kesalahan lagi.

\section{METODE PENELITIAN}

Penelitian ini merupakan penilitian deskriptif kualitatif. Adapun subjek penelitian ini siswa kelas X MIPA 2 dengan jumlah 36 siswa yang sudah mempelajari materi persamaan dan pertidaksamaan nilai mutlak. Instrumen yang digunakan dalam penelitian ini adalah tes tertulis bentuk uraian dan wawancara. Hal ini didasarkan pada pertimbangan bahwa tes ini menuntut kemampuan siswa untuk dapat menghubungkan pengetahuan yang telah mereka peroleh untuk menyelesaiakan soal persamaan dan pertidaksamaan nilai mutlak. Teknik pengumpulan data yang digunakan penelitian ini adalah instrumen tes esai sebanyak 5 soal esai dan wawancara. Sebelum dilaksanakan analisis data dilaksanakan terlebih dahulu validitas intrumen soal tes, untuk mengetahui kesalahan siswa menggunakan analisis diskriptif (Ferdianto, 2019). Adapun indikator jenis kesalahan dalam menyelesaikan masalah menurut Polya yang akan diteliti dalam penelitian ini disajikan pada Tabel 1.

\section{HASIL DAN PEMBAHASAN}

Berdasarkan jawaban siswa terhadap soal tes yang telah dikerjakan, selanjutnya dilakukan analisis untuk mengetahui jenis-jenis kesalahan yang dilakukan siswa. Menurut hasil analisis tersebut, diketahui bahwa terdapat empat jenis kesalahan yang dilakukan siswa yaitu: kesalahan memahami soal, kesalahan menyusun rencana, kesalahan melaksanakan rencana, dan kesalahan memeriksa kembali solusi yang diperoleh. Keempat jenis kesalahan tersebut disajikan pada Gambar 1.

Berdasarkan Gambar 1 dapat diketahui bahwa kesalahan siswa pada materi persamaan dan pertidaksamaan nilai mutlak dalam memahami masalah lebih banyak dilakukan disetiap nomor soal. Adapun persentase dari masingmasing jenis kesalahan yang dilakukan siswa disajikan pada Tabel 2. 
Tabel 1. Indikator Kesalahan dalam Menyelesaikan Masalah Berdasarkan Polya

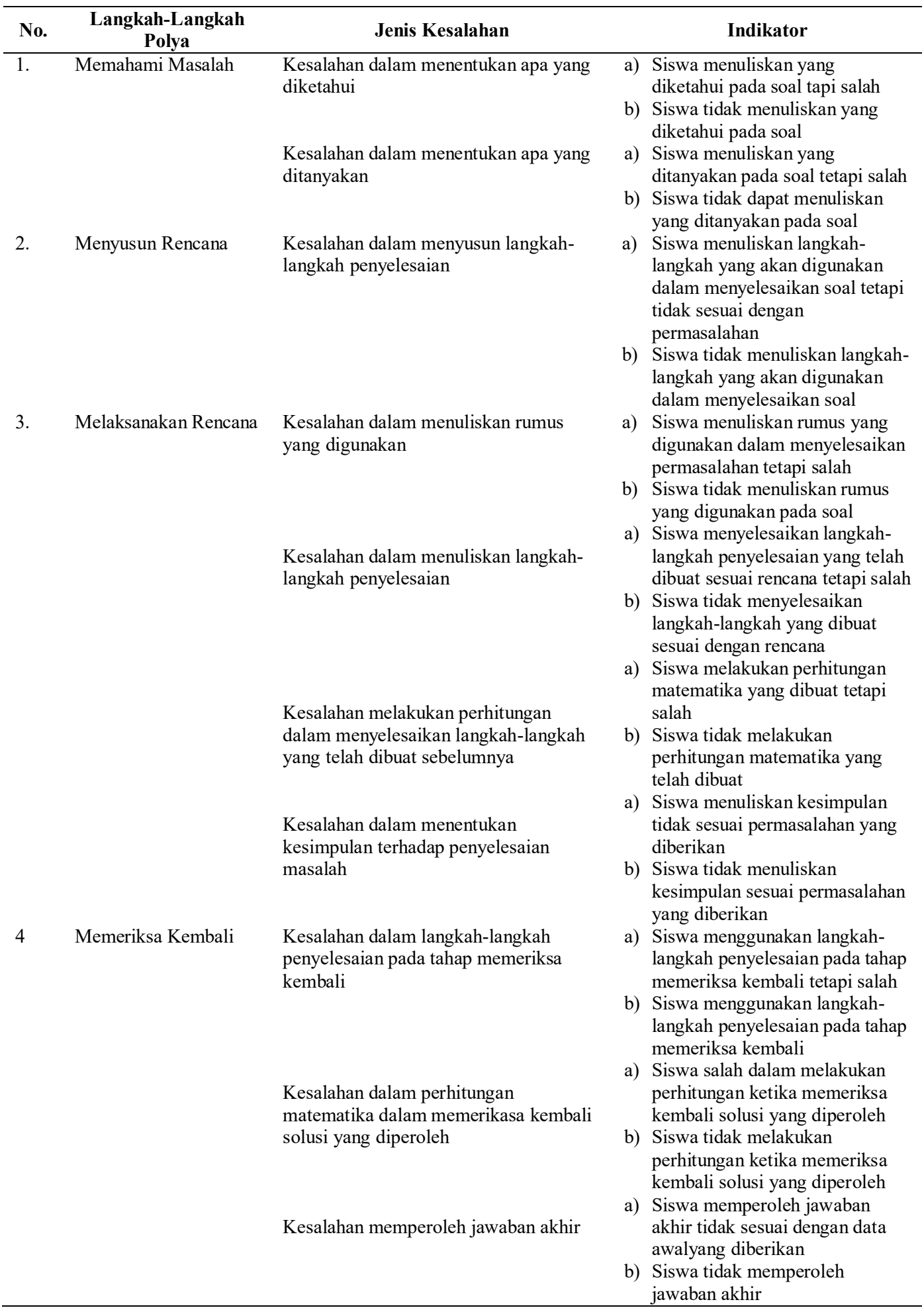




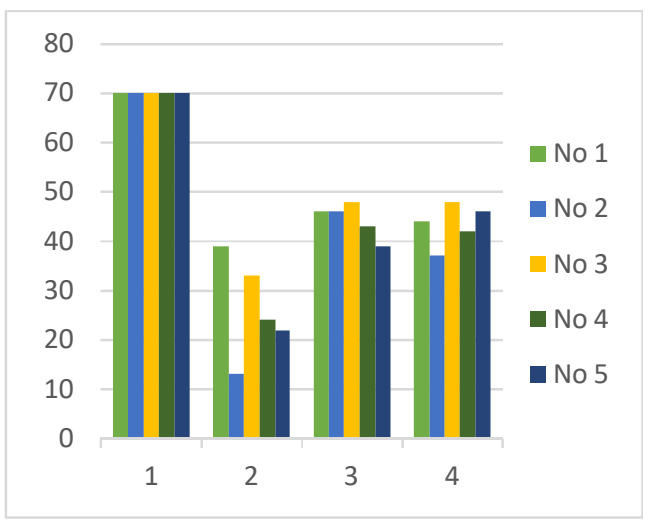

Keterangan:

(1) Memahami Soal $\quad$ (3) Melaksanakan Rencana

(2) Menyusun Rencana

(4) Memeriksa Kembali

Gambar 1. Diagram Kesalahan Berdasarkan Polya

Dari Tabel 2 dapat diketahui bahwa kesalahan yang paling banyak dilakukan siswa yaitu kesalahan dalam memahami masalah dengan persentase sebesar 38\%. Berdasarkan hasil wawancara diketahui penyebab siswa melakukan jenis kesalahan ini adalah siswa ingin cepat menyelesaikan soal tanpa menuliskan apa yang diketahui dan ditanyakan pada soal. Hal ini sesuai dengan hasil pekerjaan siswa pada Gambar 2 yaitu siswa tidak terbiasa menyertakan yang diketahui dan ditanyakan pada Gambar 2.

Tabel 2. Persentase Kesalahan Siswa Berdasarkan Polya

\begin{tabular}{clc}
\hline No. & $\begin{array}{c}\text { Langkah-Langkah } \\
\text { Polya }\end{array}$ & Persentase \\
\hline 1. & Memahami Masalah & 38 \\
2. & Menyusun Rencana & 14 \\
3. & Melaksanakan Rencana & 24 \\
4. & Memeriksa Kembali & 24 \\
\hline
\end{tabular}

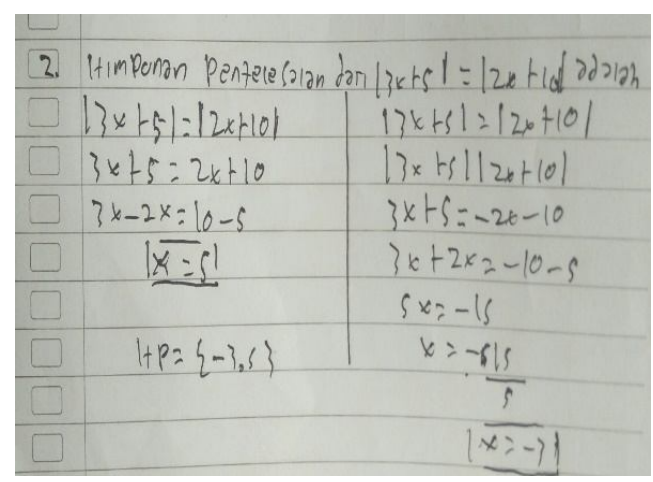

Gambar 2. Kesalahan Memahami Masalah

Dari Gambar 2, indikator pada memahami masalah yaitu siswa tidak menuliskan yang diketahui dan ditanya pada soal. Berdasarkan jawaban yang ditulis oleh siswa terlihat bahwa siswa belum memahami masalah dengan baik sehingga siswa tidak menyertakan yang diketahui dan ditanya pada soal.

Kesalahan menyusun rencana memiliki persentase sebesar $14 \%$. Berdasarkan hasil wawancara diketahui penyebab siswa melakukan kesalahan jenis ini adalah siswa masih kurang tepat dalam menyusun langkah-langkah penyelesaian dalam soal. Hal ini sesuai dengan hasil pekerjaan siswa yaitu siswa dalam menyelesaikan masalah dengan langkah-langkah yang belum tepat pada Gambar 3.

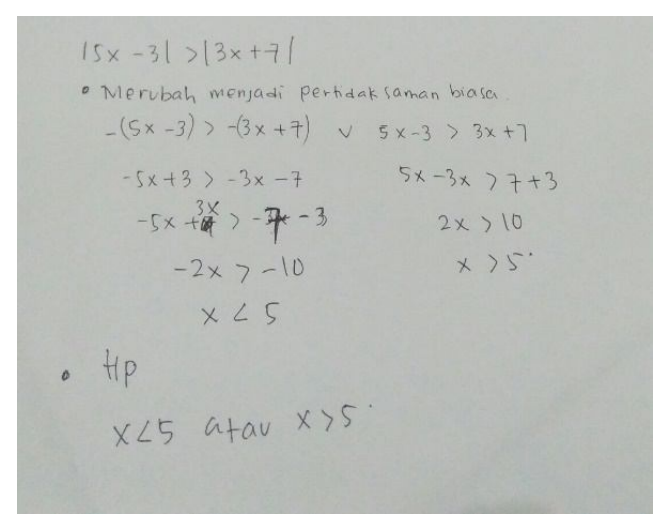

Gambar 3. Kesalahan Menyusun Rencana 
Dari Gambar 3, indikator pada menyusun rencana yaitu siswa menuliskan langkah-langkah yang akan digunakan dalam menyelesaikan soal tetapi tidak sesuai dengan permasalahan pada soal tersebut. Berdasarkan jawaban yang ditulis oleh siswa terlihat bahwa siswa belum menyusun rencana dengan baik sehingga siswa tidak menyusun startegi dan menyelesaikan masalah dengan tepat.

Kesalahan melaksanakan rencana dan memeriksa kembali memiliki persentase yang sama yaitu sebesar $24 \%$. Berdasarkan hasil wawancara diketahui penyebab siswa melakukan jenis kesalahan ini adalah siswa kurang teliti dalam melakukan perhitungan matematika untuk menyelesaikan model matematika yang telah mereka buat dan siswa juga kurang hati-hati dalam menentukan kesimpulan terhadap permasalahan yang diberikan. Hal ini sesuai dengan hasil pekerjaan siswa pada Gambar 4.

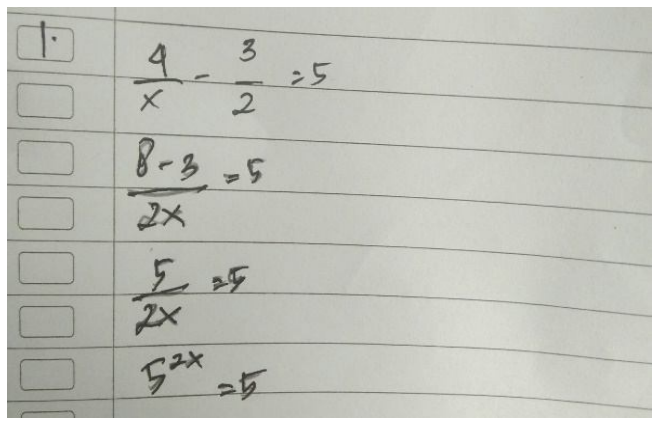

Gambar 4. Kesalahan Melaksanakan Rencana

Dari gambar 4, pada kesalahan melaksanakan rencana yaitu siswa tidak tepat dalam menyelesaikan model matematika pada soal persamaan dan pertidaksamaan nilai mutlak yang telah dibuatnya sesuai dengan langkah- langkah penyelesaian yang telah disusun dan ketidakpahaman dalam konsep eksponen, yaitu siswa juga kurang tepat menuliskan operasi dalam perhitungan, kurang tepat dalam menghitung, dan tidak menuliskan kesimpulan sesuai dengan permasalahan yang diberikan.

Berdasarkan hasil wawancara diketahui penyebab siswa melakukan kesalahan jenis ini adalah karena siswa tidak terbiasa untuk memeriksa kembali solusi yang diperoleh sehingga dalam memeriksa kembali solusi yang diperoleh, siswa tidak menggunakan langkahlangkah yang runtut (sistematis); siswa kurang tepat dalam perhitungan matematika dalam memeriksa kembali solusi yang diperoleh; dan siswa kurang tepat memperoleh jawaban akhir. Hal ini terlihat dari hasil pekerjaan siswa ketika siswa menuliskan jawaban tanpa melalui langkah-langkah yang seharusnya diselesaikan terlebih dahulu pada Gambar 5.

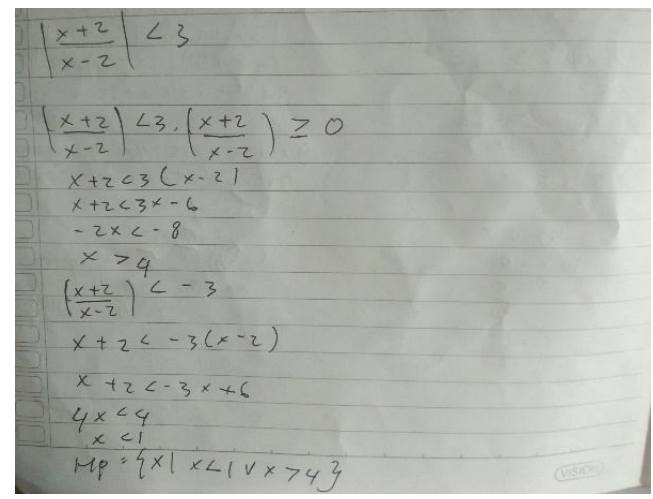

Gambar 5. Kesalahan Memeriksa Kembali

Hal ini sejalan dengan penelitian Sulistyorini \& Setyaningsih (2016) yang menyatakan bahwa kesulitan siswa saat melihat kembali atau pada indikator memeriksa kembali jawaban, siswa tidak tahu cara memeriksa kembali dengan benar, siswa tidak dapat mengatur waktu 
pengerjaan dengan baik dan siswa malas untuk mengecek kembali jawaban (Hartinah. 2019).

\section{PENUTUP}

Dari hasil penelitian analisis kesalahan siswa dalam menyelesaikan soal persamaan dan pertidaksamaan nilai mutlak berdasarkan langkah penyelesaian polya pada siswa kelas X MIPA 2 SMA Negeri 1 Gegesik didapatkan kesimpulan sebagai berikut. Jenis-jenis kesalahan yang dilakukan siswa antara lain sebagai berikut. (1) Kesalahan memahami soal, dapat dilihat dari hasil pekerjaan siswa ketika menuliskan apa yang diketahui dan ditanya dari soal yang diberikan, yaitu terdapat kata penting yang sering tidak dituliskan siswa. (2) Kesalahan menyusun rencana, dapat dilihat dari hasil pekerjaan siswa yaitu ketika siswa masih kurang tepat dalam menyusun langkah-langkah penyelesaian dalam soal serta tidak menuliskan metode dan langkah-langkah yang akan mereka gunakan dalam menyelesaikan model matematika yang telah dibuatnya. (3) Kesalahan melaksanakan rencana, dilihat dari hasil pekerjaan siswa yaitu ketika siswa kurang teliti dalam melakukan perhitungan matematika untuk menyelesaikan model matematika yang telah mereka buat dan siswa juga kurang hati-hati dalam menentukan kesimpulan terhadap permasalahan yang diberikan. (4) Kesalahan memeriksa kembali solusi yang diperoleh, dilihat dari hasil pekerjaan siswa yaitu ketika siswa kurang tepat memeriksa kembali langkah-langkah penyelesaian pada tahap memeriksa kembali, siswa kurang tepat dalam perhitungan matematika dalam memeriksa kembali solusi yang diperoleh, dan siswa kurang tepat memperoleh jawaban akhir.

\section{DAFTAR PUSTAKA}

Brown, J., \& Kim, S. (2016). Mathematics: Identifying and Addressing Student Errors.

Elbrink, Megan. (2008). Analyzing and Addressing Common Mathematical Errors in Secondary Education. B.S Undergraduate Mathematics Exchange. 5(1).

Ferdianto, F. Yesino, L. (2019). Analisis Kesalahan Siswa dalam Menyelesaikan Soal Pada Materi SPLDV Ditinjau dari Indikator Kemampuan Matematis. SJME (Supremum Journal of Mathematics Education), 32-36.

Fitria, T. N. (2013). Analisis Kesalahan Siswa dalam Menyelesaikan Soal Cerita Bernahasa Inggris Pada Materi Persamaan dan Pertidaksamaan Linear Satu Variabel. MATHEdunesa Jurnal Ilmiah Pendidikan Matematika. 2(1).

Khiat, H. (2010). A Grounded Theory Approach: Conceptions of Understanding in Egineering Mathematics Learning. The Quantum Report. 15, pp. 14591488.

Lipianto, D., \& Budiarto, M. T. (2013). Analisis Kesalahan Siswa dalam Menyelesaikan Soal yang Berhubugan dengan Persegi dan Persegipanjang Berdasarkan Taksonomi Solo Plus Pada Kelas VII. MATHEdunesa Jurnal Ilmiah Pendidikan Matematika. 2(1). 
Lya, S. Pramesti, D. Rini, J. (2019). Analisis Kemampuan Pemecahan Masalah Peserta didik Berdasarkan Strategi Polya pada Model Pembelajaran Problem Based Learning Berbasis Hands On Activity. Journal of Medives: Journal of Mathematics Education IKIP Veteran Semarang, 223-236.

Malik, N. (2011). Analisis Kesalahan Siswa Kelas VII SMP 4 Kudus dalam Menyelesaikan Soal Matematika pada Pokok Bahasan Segiempat dengan Panduang Kriteria Polya. Skripsi UNNES Semarang. Tidak diterbitkan.

Polya, G. 1973. How to Solve it (New of Mathematical Method). Second Edition. New Jersey: Prince University Press.
Purnamasari, I. \& Setiawan, W.(2019). Kemampuan Pemecahan Masalah Matematis Siswa SMP pada Materi SPLDV Ditinjau dari Kemampuan Awal Matematika (KAM). Journal Of Medives : Journal of Mathematics Education IKIP Veteran Semarang, 3(2), 207-215.

Sri Adi Widodo dan A. A. Sujadi. 2015. Analisis Kesalahan Mahasiswa dalam Memecahkan Masalah Trigonometri. Jurnal Sosiohumaniora. 1(1), $51-63$.

Hartinah, S. dan Ferdianto, F. 2019. Prosiding Seminar Nasional Pendidikan Matematika (SNPM) 1 (1), 484-492

Sulistyorini, S., \& Setyaningsih, N. (2016). Analisis Kesulitan Siswa dalam Pemecahan Masalah Soal Cerita Matematika Siswa SMP. 